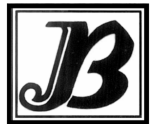

J. bio-sci. 15: 89-98, 2007

ISSN 1023-8654

http://www.banglajol.info/index.php/JBS/index

\title{
PARTIAL PURIFICATION OF DEAMIDASE FROM GERMINATING WHEAT (TRITICUM AESTIVUM L.) SEEDS AND ITS APPLICATION FOR THE IMPROVEMENT OF FUNCTIONAL PROPERTIES OF WHEAT GLUTEN
}

\author{
A T M Mijanur Rahman ${ }^{1^{*}}$, N K Sana, Md Masudul Hasan Khan, B C Sarkar, E M Huque 2 \\ and Shaha Ranajit Kumar \\ Department of Biochemistry \& Molecular Biology \\ 1Department of Applied Nutrition \& Food Technology, Islamic University of Kushtia \\ 2Department of Chemistry, University of Rajshahi, Rajshahi - 6205, Bangladesh
}

\begin{abstract}
Enzyme with deamidase activity was found in the germinating wheat seeds. The activity appeared in the seeds after 24 hours of germination and reached its maximum value after 48 hours and then declined rapidly. Protein deamidase from germinating wheat seeds was further purified by salting out with phosphate salts and by subsequent chromatography on gel filtration and DEAE-cellulose column chromatography. Polyacrylamide slab gel electrophoresis showed the purified enzyme to be homogeneous. The molecular weight was determined to be $59 \mathrm{kDa}$ by gel filtration and $60 \mathrm{kDa}$, by SDSPolyacrylamide slab gel electrophoresis (SDS-PAGE). The optimum $\mathrm{pH}$ and temperature of the purified enzyme were found to be 6.9 and $32^{\circ} \mathrm{C}$, respectively. The functional properties of wheat gluten were investigated after treating with it purified deamidase enzyme from germinating wheat seeds at pH 6.9 at $32^{\circ} \mathrm{C}$. The functional properties such as solubility, emulsification and foam formation of deamidase treated gluten were improved greatly as compared to that of native gluten. The solubility of the deamidase treated gluten was remarkably high in the $\mathrm{pH}$ range of 6 to 8 , in which the native gluten was insoluble. It was apparent that the improvement of functional properties of wheat gluten was mainly due to the deamidation induced by wheat deamidase at $\mathrm{pH} 6.9$ and $32^{\circ} \mathrm{C}$.
\end{abstract}

Key words: Wheat seeds, Deamidase, Deamidation, Wheat gluten, DEAE-cellulose, SDS-PAGE.

\section{Introduction}

Wheat is the national staple food in forty-three countries and second staple food crop of Bangladesh. Now a day's wheat provides almost $20 \%$, while rice provides about $21 \%$ of the food calories for the people of the entire world. The whole wheat grain contains approximately: water 13\%; protein $11.5 \%$; fat 2\%; carbohydrate 70\%; fiber 2\%; ash 1.5\% (Purseglov 1972). Wheat products are probably the most widely used articles of human diet. The wheat flour is used for making breads, cakes, crackers, biscuits, pastry etc. Wheat is also extensively used in the manufacture of beer and other alcoholic beverages and industrial alcohol. It is also an excellent feed for livestock.

Wheat gluten is a unique and complex material, which gives wheat flour its stretch ability and strengh. Gluten is only slightly soluble in water and aqueous buffers. It dissolves only in organic solvents, acidic or alkaline solutions, or by addition of detergents, denaturing agents, or compounds that cleave disulfide bonds. As wheat gluten is a typical insoluble protein for which it is desirable to extend its utilization in food application because of its abundant supply as a byproduct of the wheat starch industry.

*Corresponding author: e-mail: manik_bio @yahoo.com 
Protein deamidation, the hydrolysis of side chain amido groups of protein-bound glutaminyl or asparaginyl residues to release ammonia, has received attention in terms of biochemistry and industrial applications. Many proteins, including enzymes and hormones, can be deamidated in vivo (Robinson and Rudd 1974, Wright 1991), leading to alterations in higher-structure and function. The physiological role of protein deamidation in cells, which is usually considered to be nonenzymatic, is speculated to be a posttranslational modification process related to the regulation of protein folding, protein breakdown, and aging (Wright 1991).

A hypothesis has been proposed (Robinson et al. 1970) that protein deamidation is a molecular clock.

Most plant storage proteins in seeds, such as cereal prolamins and legume globulins, contain a high level of glutamine residues. The abundant amido groups in these proteins are thought to serve as a nitrogen source for seed germination. Deamidation of proteins preceding their proteolytic degradation was observed in germinating seeds (Daussant et al. 1969 and Kumar et.al 1980) and increased susceptibilities of deamidated proteins to proteases have been inferred in plant storage proteins (Kumar et al. 1980, 1999).

In the food protein industry, protein deamidation is regarded as a promising method to improve protein functionality in food systems (Riha et al. 1996, Hamada 1994 and Schwenke 1997). Deamidations of food proteins have been investigated by various methods [reviewed in (Riha et al. 1996 and Schwenke 1997)] such as mild acid treatment, anion-catalyzed deamidation, dry heating under mild alkaline conditions, and thermal treatment. Although deamidations by these treatments improved protein functionalities, there were undesired side-effects, such as concomitant peptide bond cleavage, unavoidably brought about by the chemical/physical treatments. Therefore, enzymatic methods have been desired because of their advantages of being selective and mild. The possibilities of the use of transglutaminase (Motoki et al. 1986, Larre et al. 1992 and Larre et al. 1993) peptidoglutaminases (Gill et al. 1985, Hamada et al. 1988 and Hamada 1992), and proteases (Kato et al. 1987, Bollecker et al. 1990 and Shih 1990) for this purpose have been explored. These enzymes, however, were unsuitable for protein deamidation because the primary catalytc reactions of transglutaminase and protease are not deamidation, and the primary substrate of peptidoglutaminases is not protein. A new enzyme is required that catalyzes the deamidation of protein as its primary reaction (Schwenke 1997 and Kato et al. 1987).

Deamidation is a very effective method to improve functional properties of food proteins and enzymatic deamidation of food proteins offers several advantages over chemical and protease-using deamidations. Many researchers have developed methods to change the solubility and functional properties of gluten. Wu et al. (1976) have found a significant improvement in the functional properties of gluten by mild acid hydrolysis. Matsudomi et al. (1986) and Kato et al. (1989) have reported that proteolytic deamidation of gluten was effective for the improvement in the functional properties. Thus much attention has been recently directed to the deamidation of proteins. However, the enzymatic deamidation of proteins is desirable to prepare deamidated proteins, because mild acid treatment of proteins causes not only denaturation but also cleavage of peptide bonds. To the best of our knowledge, till now no specific deamidating enzyme is known which acts on protein at pH 6.9. So deamidase, purified from germinating wheat seeds (Vaintraub et.al. 1992) may open a new possibility in changing the functional properties of food proteins.

In this study we gave attention to the purification of deamidating enzyme (deamidase) from germinating wheat seeds and improvement of functional properties (solubility, emulsifying and foaming) of wheat gluten by treating with purified deamidase from germinating wheat seeds. 


\section{MATERIALS AND METHODS}

\section{Plant material}

Wheat (Triticum aestivum,L.) seeds were collected from Bangladesh Agriculture research Institute (BARI), substation of Ishwardi, pabna. The seeds were soaked in distilled water for $6 \mathrm{hrs}$, germinated in the dark at $25^{\circ} \mathrm{C}$ for $24 \mathrm{~h}, 48 \mathrm{~h}, 72 \mathrm{~h}$ and $96 \mathrm{~h}$ including soaking time. The germinated seeds at different hours stored separately in the deep freeze $\left(-10^{\circ} \mathrm{C}\right)$ for further experimental purpose.

\section{Enzyme extraction}

Twenty grams of germinated wheat seeds (germinated at $48 \mathrm{~h}$ ) were taken in a pre-cooled mortar and pasted with a pestle and homogenized with cold de-ionized distilled water in a ratio of 3:5 (weight of dry seeds/water volume) and then centrifuged at $6 \times 10^{3} \mathrm{rpm}\left(\mathrm{at} \mathrm{2}^{\circ} \mathrm{C}\right)$ for 10 minutes by a refrigerated centrifuge machine. After centrifugation, the clear supernatant solution (water extract) was taken as a crude extract of the enzyme.

\section{Purification of deamidase}

All enzyme purification steps were carried out at $4^{\circ} \mathrm{C}$. A mixture of Sodium dihydrogen phosphate $\left(\mathrm{NaH}_{2} \mathrm{PO}_{4}\right)$ and Dipotasium hydrogen phosphate $\left(\mathrm{K}_{2} \mathrm{HPO}_{4}\right)$ in the ratio of 83:17 was added to the crude water extract and dissolved the salts by gentle stirring in an ice bath for keeping the temperature below $5^{\circ} \mathrm{C}$. The solution was centrifuged at $6000 \mathrm{rpm}$, for 15 minutes at $4^{\circ} \mathrm{C}$ and the precipitates was discarded out. The supernatant was then dialyzed (first in de-ionized distilled $\mathrm{H}_{2} \mathrm{O}$, for $12 \mathrm{~h}$ and then in $50 \mathrm{mM}$ phosphate buffer, for over night, at pH 6.8, temperature $4^{\circ} \mathrm{C}$ and were concentrated to $30 \mathrm{ml}$ in freeze dryer.

\section{Gel filtration}

The concentrated crude extract after dialysis with $50 \mathrm{mM}$ phosphate buffer, $\mathrm{pH} 6.8,4^{\circ} \mathrm{C}$ was loaded onto a Sephadex G-75 gel column $(2.5 \times 120 \mathrm{~cm})$, which was equilibrated with the same buffer. The column was eluted with $50 \mathrm{mM}$ phosphate buffer, $\mathrm{pH} 6.8$, at a flow rate of $1.0 \mathrm{ml} \mathrm{min}^{-1}$. Absorbance of each fraction at $280 \mathrm{~nm}$, deamidase activities and protein concentration were measured and the active fractions were collected.

\section{DEAE-cellulose column chromatography}

The enzymatically active protein fractions after gel filtration were collected and dialyzed against $50 \mathrm{mM}$ phosphate buffer, $\mathrm{pH} 6.8$ for overnight and then concentrated $\mathbf{b}$ its $1 / 4^{\text {th }}$ volume by freeze dryer and applied to a DEAE-cellulose column $\left(32 \times 1.0 \mathrm{~cm}\right.$, flow rate $\left.25 \mathrm{ml} \mathrm{h}^{-1}\right)$ previously equilibrated with $50 \mathrm{mM}$ phosphate buffer, $\mathrm{pH} 6.8$ and eluted with the same buffer containing a linear gradient of $\mathrm{NaCl}$ (100-500 mM). Absorbance at $280 \mathrm{~nm}$, protein concentration and deamidase activities were determined. The active fractions were collected.

\section{Determination of deamidase activity}

Working substrate globulins was prepared from wheat seeds by the method of Thanh and Shibasaki (1976). A mixture consisting of $0.2 \mathrm{ml}$ of substrate solution $(3 \mathrm{mg}$ of wheat proteins $/ 1 \mathrm{ml}$ in phosphate-citrate buffer, $\mathrm{pH}$ 6.8) and $0.4 \mathrm{ml}$ enzyme solution was incubated at $37^{\circ} \mathrm{C}$ in a temperature controlled water bath for 45 minutes. In control experiments the substrate solution was substituted by $0.2 \mathrm{ml}$ of the substrate buffer. After incubation, the reaction was stopped by adding $0.5 \mathrm{ml}$ of $4 \%$ solution of $\mathrm{Na}_{2} \mathrm{~B}_{4} \mathrm{O}_{7}, 10 \mathrm{H}_{2} \mathrm{O}(\mathrm{pH}$ about 10$)$ to bring up the $\mathrm{pH}$ of the incubation mixture nearly to 10 . The evolved ammonia was distilled isothermally into $1 \mathrm{M} \mathrm{H}_{2} \mathrm{SO}_{4}$ and determined by a variant of the Nessler's method (Middleton 1960). The enzyme activity was expressed in $\mathrm{U}$ ( $\mathrm{n} \mathrm{mol}$ of $\mathrm{NH}_{3}$ released per minute). 


\section{Molecular weight of deamidase}

\section{a) Gel Filtration}

The molecular weight of the purified deamidase was determined by gel filtration on Sephadex G-75 column $(150 \times 3.0 \mathrm{~cm})$ equilibrated with $50 \mathrm{mM}$ phosphate buffer, $\mathrm{pH} 6.8$, following the procedure established (Andrews 1965). Trypsin inhibitor (12.028 kDa), carbonic anhydrase ( $29 \mathrm{kDa}$ ), ?-amylase ( $58 \mathrm{kDa}$ ), bovine serum albumin ( $68 \mathrm{kDa}$ ), phosphorylase-b ( $97.4 \mathrm{kDa}$ ) and ß-galactosidase (116 kDa) were used as marker proteins (Weber and Osborn 1966).

(b) Electrophoresis: SDS-PAGE was performed according to the method of Laemmli (1970) on a Bio-rad mini electrophoresis system. The standard proteins were ßlactoglobulin ( $18.4 \mathrm{kDa}$ ), carbonic anhydrase ( $29 \mathrm{kDa}$ ), ovalbumin ( $43 \mathrm{kDa}$ ), bovine serum albumin ( $68 \mathrm{kDa}$ ), phosphorylase-b ( $97.4 \mathrm{kDa}$ ) and $\beta$ galactosidase $(116 \mathrm{kDa})$. PAGE was performed with $7 \%$ gels and the electrophoresis was run at $2000 \mathrm{~V}$ and $50 \mathrm{~A}$.

\section{Optimum $\mathrm{pH}$ of the enzyme}

To study the effect of $\mathrm{pH}$ on enzyme activity, the enzyme solutions (0.6\%) were dialyzed against $50 \mathrm{mM}$ buffer of different pH (pH 2.0-3.0, AcONa - HCl; pH 4.0 - 5.0, AcONa - $\mathrm{CH}_{3} \mathrm{COOH}$; $\mathrm{pH} 5.5$ - 8.0, $\mathrm{NaH}_{2} \mathrm{PO}_{4}$ $\mathrm{Na}_{2} \mathrm{HPO}_{4} ; \mathrm{pH} 8.5-9.0, \mathrm{Na}_{2} \mathrm{~B}_{4} \mathrm{O}_{7}-\mathrm{HCl} ; \mathrm{pH} 9.5, \mathrm{Na}_{2} \mathrm{~B}_{4} \mathrm{O}_{7}-\mathrm{Na}_{2} \mathrm{CO}$.) for 24 hrs with frequent change of buffers. After necessary adjustment of $\mathrm{pH}$ by adding $0.1 \mathrm{~N} \mathrm{HCl}$ or $0.1 \mathrm{~N} \mathrm{NaOH}$, the enzyme activities were assayed using globulin as substrate.

\section{Optimum temperature of the enzyme}

In order to determine the optimum temperature, the enzyme solutions $(0.5 \%)$ in $50 \mathrm{mM}$ phosphate buffer, $\mathrm{pH}$ 6.9 , were incubated at various temperatures ranging from $10^{\circ} \mathrm{C}-90^{\circ} \mathrm{C}$ for 15 minutes in a temperature controlled water bath and the activities were assayed.

\section{Preparation of gluten}

An insoluble wheat protein complex, gluten, was prepared from flour dough washed until the washings were free from soluble protein. The gluten ball thus obtained was dialyzed against distilled water and then freezedried in a freeze-dryer.

\section{Deamidase treatment of gluten}

To ten $\mathrm{ml}$ of a $0.1 \%$ gluten solution in phosphate-citrate buffer, $(\mathrm{pH} 6.9) 0.5 \mathrm{mg}$-purified deamidase was added. The mixture was incubated at $32^{\circ} \mathrm{C}$ for 30 minutes. After incubation, the reaction mixture was immediately heated for 30 seconds at $90^{\circ} \mathrm{C}$ to inactivate the deamidase. The enzymatically treated gluten solution thus obtained was dialyzed against distilled water for $48 \mathrm{hrs}$ at $4^{\circ} \mathrm{C}$ to remove ammonia and then freeze-dried. Control gluten was similarly treated without deamidase.

\section{Determination of solubility of gluten}

$0.05 \%$ gluten or deamidated gluten solutions were adjusted to different $\mathrm{pH}$ with $0.1 \mathrm{~N} \mathrm{HCl}$ or $\mathrm{NaOH}$, stirred for 10 minutes with a magnetic stirrer, and centrifuged at $12,000 \times \mathrm{g}$ for 15 minutes. The absorbance of the supernatant was measured at $280 \mathrm{~nm}$. The solubility was represented as \% absorbance of the supernatant of $0.05 \%$ native gluten in $0.1 \mathrm{~N} \mathrm{NaOH}$.

\section{Measurement of emulsifying properties}

The emulsifying property of freeze-dried samples was determined by the method of Pearce and Kinsella (1978). To prepare an emulsion, $1 \mathrm{ml}$ corn oil and $3 \mathrm{ml}$ enzyme solution in $0.1 \mathrm{M}$ phosphate buffer, pH 7.4, 
were shaken together and homogenized in an Ultra Turrax (Hansen and co., Germany) at 12,000xg for 1 minute at $20^{\circ} \mathrm{C}$. Fifty micro liters of the emulsion was taken from the bottom of the container at various times and diluted with $5 \mathrm{ml} 0.1 \%$ SDS solution. The absorbance of the diluted emulsions was then determined at $500 \mathrm{~nm}$. Emulsifying activity was determined from the absorbance measured immediately after the emulsion formation. The emulsion stability was defined as the half time ( $\mathrm{min}$ ) for turbidity of the diluted solution, estimating from the curves of emulsion turbidity. Values reported are means of triplicate.

\section{Measurement of foaming properties}

The foaming property of proteins was determined according to the conductivity method of Kato et al. (1983). Electric conductivity of foams was measured when air was introduced for $15 \mathrm{sec}$ into $5 \mathrm{ml}$ of $0.1 \%$ enzyme solution in $0.02 \mathrm{M}$ phosphate buffer, $\mathrm{pH} 7.4$, in a vertical glass column $(2.4 \times 30 \mathrm{~cm})$ with a glass filter $(\mathrm{G}-4)$ at a constant flow rate. The foam stability is expressed as $C_{0} \times d t / d c$, where $d c$ is the change in conductivity occurring during the time interval $\mathrm{dt}$, and $\mathrm{C}_{0}$ is the conductivity at zero time obtained by extrapolating the plot of linear conductivity vs time. Foaming power was defined as the maximum conductivity of foams produced after aeration. The foam stability was shown as the time for the disappearance of the conductivity. Values obtained are means of triplicate samples.

\section{Protein assay}

Protein concentration of each fraction was determined by UV-visible spectrophotometer at $280 \mathrm{~nm}$. The amount of protein was estimated by the published method of Lowry et al. (1951) using BSA as standard.

\section{Chemicals}

BSA, Acryl amide, Sodium Dodecyl Sulfate, and Sephadex G75 were purchased from Sigma Chemicals Ltd., USA. Standard proteins, DEAE-cellulose were purchased from Pharmacia Fine Chemicals Ltd., Sweden. All other chemicals used for th is research was commercially available and were of high purity.

\section{Results and Discussion}

\section{Time course study}

In the germinating wheat seeds, the deamidase activity in crude extract was not observed within 20 hrs. The deamidase activity appeared in crude extract after $24 \mathrm{hrs}$ and showed its maximum activity at 48-52 hrs (Fig. 1) after germination and then declined rapidly. It is interesting that no deamidase activity was observed in early germination; so, we used to carry out our experiment using wheat seeds germinated for 48 hrs.

\section{Gel filtration}

The enzyme was eluted as two peaks namely F-1 and F-2 (Fig. 2). It was found that only F1 fraction contained the deamidase activity while the F2 fraction showed no activity. The F1 peak containing the enzyme activity was pooled, concentrated and further purified by DEAE-cellulose column chromatography.

\section{DEAE-cellulose column chromatography}

The components of F-1 fraction from gel filtration were separated into two peaks namely F-1a and F-1b (Fig. 3) using sodium chloride gradient (0.1-0.5 M) on DEAE-cellulose column. F-1a fraction showed deamidase activity while $\mathrm{F} 1 \mathrm{~b}$ fraction possessed no enzymatic activity. The homogeneity of the deamidase existing fraction (F-1a) was checked by sodium dodecylsulphatepolyacrylamide slab gel electrophoresis (SDSPAGE). This fraction gave single band on SDS-PAGE (Fig.4) indicating that the enzyme was in pure form. 


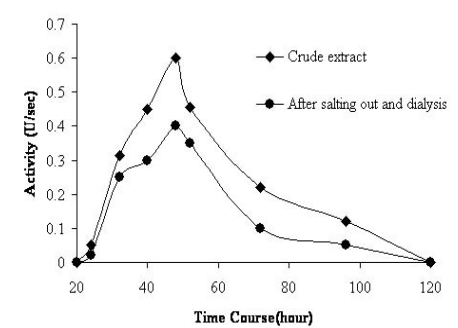

Fig. 1.

Time-course of wheat protein deamidase activity during germination.

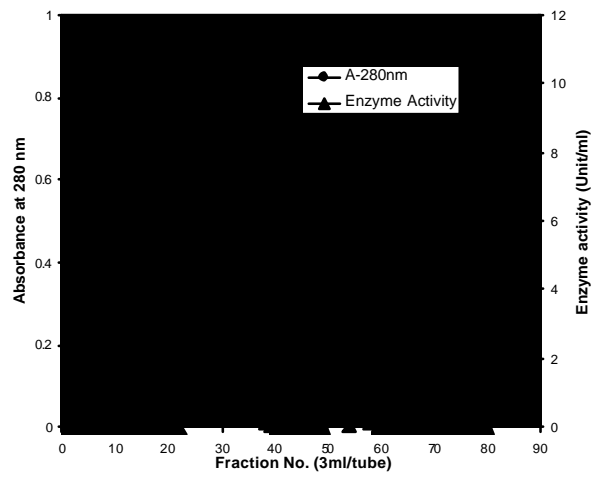

Fig. 2. Gel filtration pattern of crude extract (After salting out and dialysis) on Sephadex G-75 column $(2.5 \times 100 \mathrm{~cm})$. The wheat protein deamidase was applied to the column of Sephadex G-75 and then the enzyme was eluted with $0.06 \mathrm{M}$ phosphate duffer, $\mathrm{pH} 6.8$.

Table 1 summarizes the purification of deamidase enzyme from germinating wheat seeds. The specific activities of the extracted enzyme increased at each purification step and the purification fold was achieved from crude extract nearly 72 . The specific activity of the final preparation was 215 units /mg.

Table 1. Purification summary of germinating wheat protein deamidase.

\begin{tabular}{|c|c|c|c|c|c|}
\hline Purification steps & $\begin{array}{c}\text { Total protein } \\
\text { (mg) }\end{array}$ & $\begin{array}{c}\text { Total activity } \\
\text { (units) }\end{array}$ & $\begin{array}{c}\text { Specific activity } \\
\text { (units/mg) }\end{array}$ & $\begin{array}{c}\text { Yield } \\
(\%)\end{array}$ & $\begin{array}{c}\text { Purification } \\
\text { (Folds) }\end{array}$ \\
\hline Crude extract & 310 & 930 & 3 & 100 & 1.00 \\
\hline $\begin{array}{c}\text { Salting out and } \\
\text { dialysis }\end{array}$ & 30.5 & 673 & 22.03 & 72.37 & 7.36 \\
\hline $\begin{array}{c}\text { Gel filtration } \\
\text { chromatography }\end{array}$ & 5.2 & 295 & 56.73 & 31.72 & 18.91 \\
\hline $\begin{array}{c}\text { DEAE-cellulose } \\
\text { chromatography }\end{array}$ & 0.87 & 187.5 & 215.5 & 20.16 & 71.83 \\
\hline
\end{tabular}

The molecular weight of the pure enzyme was determined by comparing their elution volume on Sephadex G-75 under identical experimental conditions. A logarithmic plot of molecular weight against relative volume gave a linear relationship and the molecular weight of the enzyme was found to be $59 \mathrm{kDa}$. In order to elucidate the sub-unit structure of the enzyme, SDS-polyacrylamide slab gel electrophoresis was performed using ßlactoglobulin (18.4 kDa), carbonic anhydrase (29 kDa), ovalbumin (43 kDa), bovine serum albumin (68 kDa), phosphorylase-b (97.4 kDa) and ß-galactosidase (116 kDa) as standard proteins under denaturing and non-denaturing conditions. The molecular weight was found to be unchanged under both the conditions indicating that the enzyme contained only one sub-unit. The standard curve was constructed by plotting log of molecular weight against relative mobility of the reference proteins (Fig.4) and the molecular weight of the 
enzyme was calculated from the plot as $60 \mathrm{kD}$. This value was in accordance with molecular weight of deamidase isolated from bovine brain (Rakov et al. 1977) but higher than the deamidases of Pseudomonas fluorescens AG (Wintzerith et al. 1980) and Yeast (Yan and Sloan 1987).

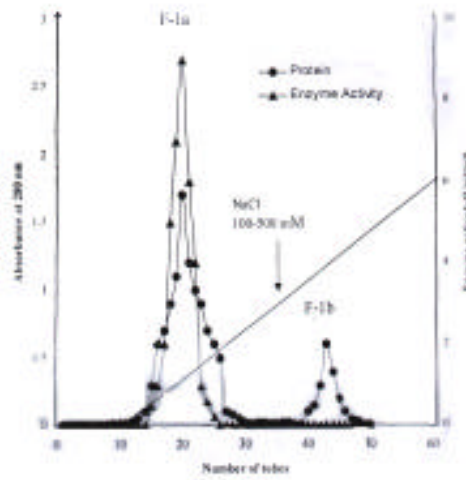

Fig. 3.

DEAE-cellulose column chromatography $(2.5 \times 100 \mathrm{~cm})$ of wheat protein deamidase. The enzyme fractions obtained from gel filtration column were applied to the DEAEcellulose column. The enzyme was eluted with $0.01 \mathrm{M}$ phosphate duffer, $\mathrm{pH} 6.8$.

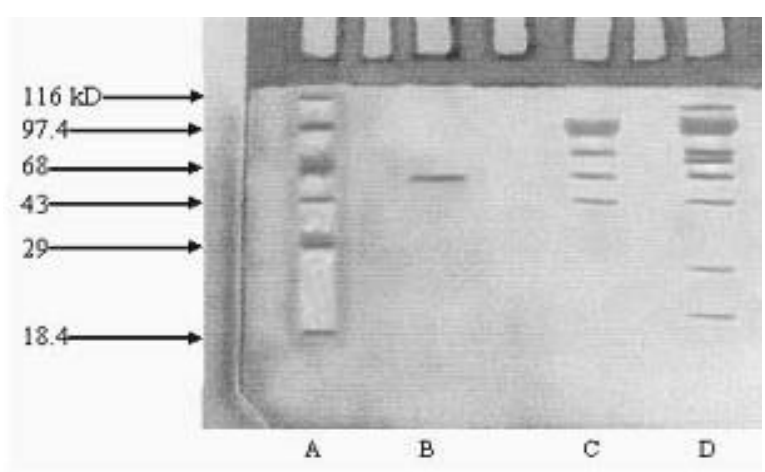

Fig. 4.

Photographic representation of the SDS- polyacrylamide slab gel electrophoresis of the various fractions obtained during the purification of deamidase for determination of molecular weight. $A=$ Marker protein solution containing standard protein mixture.

$\mathrm{B}=$ After DEAE-cellulose column $\mathrm{C}=$ After gel filtration column $\mathrm{D}=$ Crude enzyme solution

The dependence of enzyme activity on the $\mathrm{pH}$ of the reaction mixture was examined at $377^{\circ} \mathrm{C}$ using various buffer solutions. The optimum $\mathrm{pH}$ of the purified enzyme was found in a range of $\mathrm{pH} 6.5-7.5$, with a maximum at pH 6.9 (Fig. 5) which is very close to that reported by Wintzerith et al. (1980) for nicotinamide deamidase $(\mathrm{pH} 7.2)$ and higher than that reported by Yan and Sloan yeast deamidase (1987).

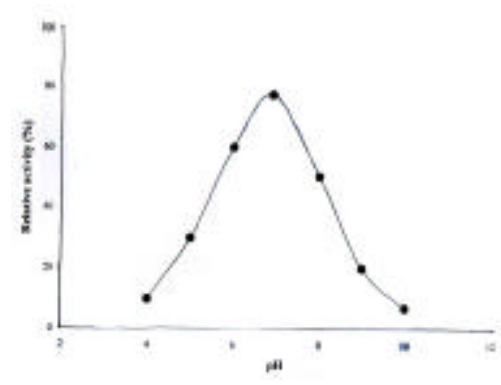

Fig. 5. Effect of $\mathrm{pH}$ on the activity of wheat seed deamidase.

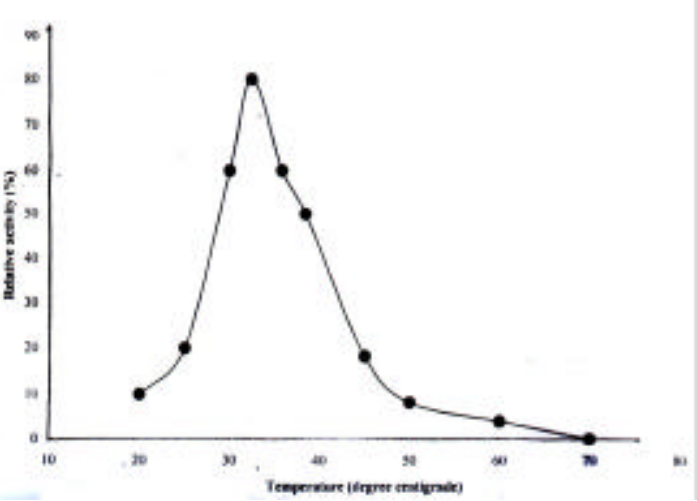

Fig. 6. Effect of temperature on the activity of wheat seed deamidase. 
Temperature of incubation was optimized by controlling the reaction mixture at $20-70^{\circ} \mathrm{C}$ at optimum pH 6.9. The activity increased with increasing temperature to $30-35^{\circ} \mathrm{C}$ (Fig. 6), followed by a sharp decline and at $70{ }^{\circ} \mathrm{C}$ complete inhibition was found.

The solubility of the native gluten and deamidase treated gluten are shown in Fig. 7. The deamidase treated gluten was more soluble in a pH range above 6 when compared with native gluten. The minimum solubility of the deamidase treated gluten was shifted to the more acidic $\mathrm{pH}$ range. This result indicated that the free carboxyl groups in gluten might have been increased by deamidation of glutaminyl and asparaginyl residues in gluten. Thus, the enhancement of solubility might have been induced mainly by the increased electrostatic repulsion and the decreased hydrogen bonding as a result of deamidation.

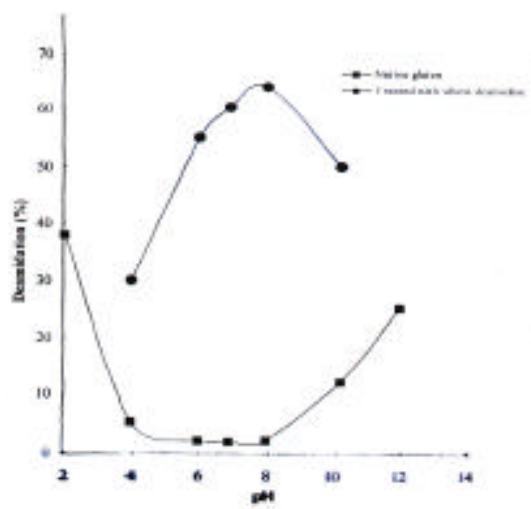

Fig. 7. Effect of $\mathrm{pH}$ on the solubility of gluten treated with wheat deamidase and native gluten.

The emulsifying activity of the deamidase treated gluten was found too higher than that of native gluten (Fig 8). In addition, the emulsion of the deamidase treated gluten was particularly stable, although the emulsion stabilities of native gluten rapidly decreased. The increase of emulsifying property was probably due to induction of an amphiphilic nature by deamidase-catalyzed deamidation.

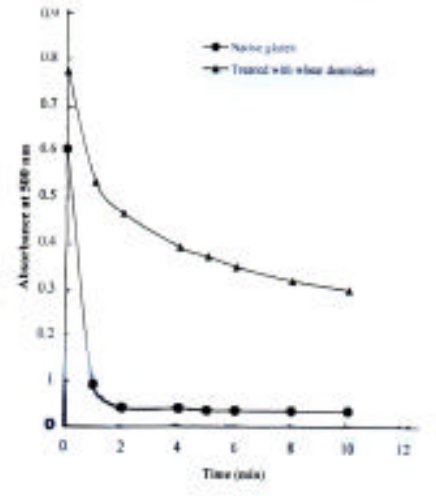

Fig. 8. Emulsifying properties of gluten treated with wheat deamidase and native gluten.

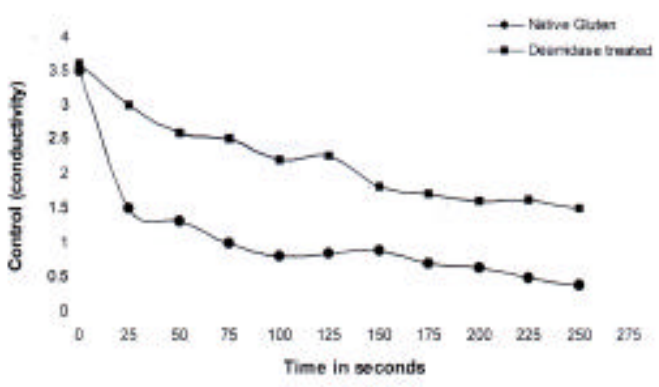

Fig. 9. Foaming properties of gluten treated with wheat deamidase and native gluten. 
The foaming property of native gluten and deamidase treated gluten are shown in Fig. 9. The foaming property of the deamidase treated gluten was also higher than hat of native gluten. This result suggests that the increased in the flexibility due to deamidation might cause an improvement of foaming properties.

Like protease, protein deamidase is useful and desirable for industrial applications, because the deamidated wheat proteins reveal good functional properties our experiment; it was observed that by treating with deamidase at $\mathrm{pH} 6.9$ the deamidated gluten could be obtained. The deamidated gluten greatly improved some functional properties such as solubility, emulsifying and foaming ability. It was suggested that under specifically controlled conditions, the deamidase treated wheat gluten (byproduct from food industry), which contain a large amount of amidated amino acids, could be a useful procedure for improving their functional properties.

The changing of protein charge by enzymatic deamidation represents a very promising method of modification of functional properties of proteins. Unlike the chemical methods of deamidation, the enzymatic transformation from neutral amide group to the carboxyl group increases the charge of protein molecule without affecting the food value of proteins. So, the enzymatic deamidation may become an easy and highly effective method of increasing the functional properties of food proteins by increasing their solubility enzyme deamidase opens possibilities of changes in functional properties of food proteins. The seed storage proteins are the natural substrate of this enzyme. It may be expected that it will carry out deep deamidations at least of those protein isolates, which are obtained from seeds.

\section{References}

Andrews P (1965) The gel filtration behavior of proteins related to their molecular weights over a wide range. Biochem. J. 96: 595-605.

Bollecker S, Viroben G, Popineau Y and Gueguen J (1990) Acid deamidation and enzymatic modification at pH 10 of wheat gliadin: influence on their fuctional properties. Sci. Aliments 10: 343-356.

Daussant J M, Neucere N J and Conkerton E J (1969) Immunochemical studies on Arachis hypogaea proteins with particular reference to the reserve proteins. II. Protein modification during germination. Plant Physiol. 44: 480-484.

Gill B P, O'Shaughnessey A J, Henderson P and Headon D R (1985) An assessment of the potential of peptidoglutaminases I and II in modifying the charge characteristics of casein and whey proteins. Ir. J. Food Sci. Technol. 9: 33-41

Hamada J S (1992) Effects of heat and proteolysis on deamidation of food proteins using peptidoglutaminase. J. Agric. Food Chem. 40: 719-723.

Hamada J S (1994) Deamidation of food proteins to improve functionality. Crit. Rev. Food Sci. Nutr. 34: 283-292.

Hamada J S, Shih F F, Frank A W and Marshall W E (1988) Deamidation of soy peptides and proteins by Bacillus circulans peptidoglutaminase. J. Food Sci. 53: 671-672.

Kato A, Lee $Y$ and Kobayashi K (1989) Deamidation and Functional properties of Food proteins by the treatment with Immobilized Chymotrypsin at alkaline pH. J. Food. Sci. 54: 1345-1347.

Kato A, Takahashi A, Matsudomi N and Kobayashi K (1983) Determination of foaming properties of proteins by conductivity measurement. J. Food. Sci. 48: $62-5$.

Kato A, Tanaka A, Lee Y, Matsudomi N and Kobayashi K (1987) Effects of deamidation with chymotrypsin at pH 10 on the functional properties of proteins. J. Agric. Food Chem. 35: 285-288.

Kumar G N, Houtz R L and Knowles N R (1999) Age-induced protein modifications and increased proteolysis in potato seed-tubes. Plant Physiol. 119: 89-99.

Kumar K G, Vencataraman L V and Appu Rao A G (1980) Chickpea seed proteins: Conformational changes in $10.3 \mathrm{~S}$ protein during germination. J. Agric. Food Chem. 28: 518-524. 
Laemmli U K (1970) Vleavage of structural proteins during the assembly of the head of bacteriophage T4. Nature 227: 680-685.

Larre C, Chiarello M, Blanloeli J Y, Chenu M and Gueguen J (1993) Gliadin modification catalyzed by guinea pig liver transglutaminase. J. Food Biochem. 17: 267-282.

Larre C, Kedzior Z M, Chenu M G, Viroben G and Gueguen J (1992) Action of transglutaminase on an 11 S seed protein (pea legumin): influence of the substrate conformation. J. Agric. Biol. Chem. 40: 1121-1126.

Lowry O H, Rosebrough N J, Farr A L and Randall R J (1951) Protein measurement with the folin phenol reagent. J. Biol. Chem. 193: 265-275.

Matsudomi N, Tanaka T, Kato A and Kobayashi K (1986) Functional properties of deamidated Gluten obtained by treating with chymotrypsin at alkaline pH. Agric. Biol. Chem. 50: 1989-94.

Middleton K R (1960) New Nessler reagent and its use in the direct Nesslerization of Kjeldahl digests. J. Appl. Chem. 10: 281-286.

Motoki M, Seguro K, Nio N and Takinami K (1986) Glutamine-specific deamidation of as1-casein by transglutaminase Agric. Biol. Chem. 50: 3025-3030.

Pearce K N and Kinsella J E (1978) emulsifying properties of proteins; Evaluation of a turbidimetric technique. J. Agric. Food Chem. 26: 716.

Purseglov J W (1972) Tropical crops Monocotyledons, $2^{\text {nd }}$ edn, pp. 294, Longman Group Ltd., London.

Rakov S S, Prozorvskii V N, Grebenshchikova O G and Kondrat'eva N A (1977). Physico-chemical properties of deamidase AG from Pseudomonas fluorescens AG possessing antitumor activity. J. Vopr Med Khim. 23(4): 503-8.

Riha W E III, Izzo H V, Zhang J and Ho C-T (1996) Nonenzymatic deamidation of food proteins. Crit. Rev. Food Sci. Nutr. 36: 225-255.

Robinson A B and Rudd C J (1974) Deamidation of glutaminyl and asparaginyl residues in peptides and proteins. Curr. Top. Cell. Regul. 268: 247-295.

Robinson A B, McKerrow J H and Cary P (1970) Controlled deamidation of peptides and proteins: an experimental hazard and a possible biological timer. Proc. Natl Acad. Sci. USA 66: 753-757.

Schwenke K D (1997) Enzyme and chemical modification of proteins. In: Food Proteins and Their Applications (Damodaran S and Paraf A eds) pp. 393-424. Marcel Dekker.

Shih F (1990) Deamidation during treatment of soy protein with protease. J. Food Sci. 55: 127-132.

Thanh V H and Shibasaki K (1976) Major proteins of soybean seeds. A straightforward fractionation and their characterization. J. Agric. Food Chem. 24: 1117-21.

Vaintraub I A, Kotova L V and Shaha R K (1992) Protein deamidase from germinating wheat grains. FEBS Letters 302: 169-171.

Weber K and Osborn M (1966) The relatibility of molecular weights determination by sodium dodecyl sulphate (SDS) polyacrylamide gel electrophoresis. J. Biol. Chem. 244: 406.

Wintzerith M, Dierich A and Mandel P (1980) Purification and characterization of a nicotinamide deamidase released into the growth medium of neuroblastoma in vitro. J. Biochem. Biophys. Acta. 613 (1): 191-202.

Wright H T (1991) Nonenzymatic deamidation of asparaginyl and glutaminyl resisues in proteins. Crit. Rev. Biochem. Mol. Biol. 26: 1-52.

Wu C H, Nakai S and Powrie W D (1976) Preparation and properties of acid solubilized gluten. J. Agric. Food Chem. 24: 504-510.

Yan C and Sloan D L (1987) Purification and characterization of nicotinamide deamidase from yeast. J. Biol. Chem. 262(19): 9082-9087. 